\title{
Audit firm characteristics and audit quality in Nigeria
}

\author{
Ilaboya Ofuan James ${ }^{1,}$, Ohiokha Friday Izien ${ }^{2}$ \\ ${ }^{1}$ Department of Accounting, Faculty of Management Sciences, University of Benin, Benin City, Nigeria \\ ${ }^{2}$ Department of Accounting, Auchi Polytechnic, Auchi, Edo State, Nigeria
}

Email address:

ofuanwhyte@gmail.com (Ilaboya O. J.), ojwhyte@yahoo.com (Ilaboya O. J.)

\section{To cite this article:}

Ilaboya Ofuan James Ohiokha Friday Izien. Audit Firm Characteristics and Audit Quality in Nigeria. International Journal of Business and Economics Research. Vol. 3, No. 5, 2014, pp. 187-195. doi: 10.11648/j.ijber.20140305.14

\begin{abstract}
This study examines the impact of audit firms' characteristics on audit quality. We proxy the dependent variable (audit quality) using the usual dichotomous variable of 1 if big 4 audit firm and 0 if otherwise. Data for the study were sourced from the financial statements of 18 food and beverage companies listed on the Nigerian Stock Exchange market within the period studied (2007-2012). The multivariate regression technique with emphasis on Logit and Probit method was used to estimate our model for the study. The choice of this approach was basically influenced by the dichotomous nature of our dependent variable and the fact that our data is both time series and cross-sectional. The findings indicate that there is a positive relationship between firm size, board independence and audit quality whereas there is a negative relationship between auditor's independence, audit firm size, audit tenure and audit quality. The study suggests the need for the Nigerian Financial Reporting Council and other regulatory bodies in line with best practices to look critically into the three years professional requirements for auditors.
\end{abstract}

Keywords: Audit Quality, Audit Tenure, Audit Independence, Board Independence

\section{Introduction}

At the thrust of the functioning of the capital market is the role of the external audit as both owners(shareholders) and the professional managers would want to rely on the report of the external auditor in furthering their sometimes divergent interest arising from agency relationship that exists(Barbadillo \& Aguilar, 2008) High-quality external audit has became an important policy issue following corporate scandals such as Enron, WorldCom, Global crossing, Cendant, Sunbeam(United States); BCCI, Independent Insurance, Equitable Life, Maxwell(United Kingdom); Metallgesellscheft(Germany), and Lever Brothers, African Petroleum, Cadbury, Savanna Bank, Wema and Intercontinental Bank (Nigeria).

The seemingly persistent bank failures in Nigeria have raised some fundamental issues on the quality of audit and the independence of the external auditor amidst others. In particular, regulators have often expressed their concern that the length of the auditor-client relationship (or auditor tenure) and executives association with auditors could impair auditor independence and thus audit quality (Daris, Soo \&Trompeter, 2003). The quality of an audit depends simultaneously on several audit firm features such as auditor specialty, auditor independence, auditor tenure, audit firm size, audit fee, auditor enterprise, audit company type. (Abedalgader Ibrahim \& Baker, 2010)

Auditors express their audit opinions on a financial statement presented to them based on audit evidence. The objective of an audit, therefore, is to plan and perform the audit to obtain appropriate audit evidence that is sufficient to support the opinion expressed in the auditor's report. Insufficient or inappropriate audit evidence may lead to wrong conclusions and this may affect the quality of the report. Hence, the issue of audit quality has received increased attention due to highly publicized audit failures culminating in corporate scandals, corporate fraud, corporate failure. This concern motivated the current study of the relationship between firm characteristics and audit quality. The issues above raise some fundamental questions: is audit tenure, audit firm type, auditor independence, audit firm size and audit fee factors that map into the auditor-client relationship and thus influences audit quality?

Against the above backdrop, the main objective of this study is to examine the relationship between audit firm characteristics and audit quality in Nigeria, using Nigerian listed companies as a reference point.

The study reveals that there is a positive relationship 
between company size, board independence and audit quality while there exists a negative relationship between audit independence, audit firm size and audit quality. While issues of firm characteristics and audit quality cannot be said to be novel in Nigeria, there exists conflicting reports on the relationship between explanatory variables and audit quality. Therefore, this study extends and contributes to extant empirical literature with a view to resolving the inconsistency.

The remainder of the paper is structured as follows: in section 2, conceptual framework on audit quality and prior empirical studies were considered, in section 3, data estimation technique was addressed. Section 4 focused on the estimation result and discussion of findings. The final section addressed conclusion and policy implications.

\section{Literature Review}

\subsection{Concept of Audit Quality}

Audit quality according to DeAngelo (1981, p.186), "is market-assessed joint probability that a given auditor will both (a) discover a breach in the client accounting system and (b) report the breach." Jackson, Moldrich and Roebuck (2008) view the quality of audits from actual and perceived quality. Actual quality shows levels of risk of material errors in financial statements that can be reduced by the auditor. Perceived quality indicates the level of confidence of users in financial statement and the auditor's effectiveness in reducing material misstatement in financial statements prepared by management. Titman and Trueman (1986) see audit quality as the accuracy of the information reported by auditors. DeAngelo definition captures attribute critically to the role played by auditors in financial statement preparation. Thus, audit quality combines the ability of an auditor to detect a breach (auditor competence) and a willingness to report such a breach (auditor independence).

Financial Reporting Council (2006b) considers five factors that influence audit quality to includes: audit firm culture, skills and personal qualities of audit partners and staff, the effectiveness of the audit process, and the reliability and usefulness of audit reporting, amongst factor that are exogenous to the auditors. Earlier studies used observable outcomes as proxies for audit quality this includes; audit opinions, auditors' selection and change, decisions, financial statements outcomes and analysts forecast. Francis (2004) reviewed 25 years of empirical researches and found that difference exists in the audit quality which can be concluded by examining different auditors. Moizer (1998) examines the issue of audit quality from a behavourial perspective, typically identifying attributes that are perceived by financial statement preparers, auditors and users that are related to audit quality. He found out that the big audit firms provide quality service.

Sutton and Lampe (1990) used a group of experts with practicing auditors to develop and evaluate a model of audit quality. Their model included 19 attributes of audit quality that they classified into three categories; planning, fieldwork and administration. Each of the 19 factors included one measure (or item).The first UK study to examine audit quality attributes was undertaken by Beatie and Fearnley (1995). They investigated finance directors of 210 listed UK companies to identify the importance of 29 desirable auditor characteristics. An exploratory factor analysis was used to identify five main factors: integrity of the firm, the technical competence of the firm, the quality of the working relationship with audit partner, the reputation of the firm and the technical competence of the audit partner.

In relation to the quality of auditing, Geiger and Raghunandan (2002) surveyed 117 US corporations with significant liquidity issues between 1996 and 1998 and observed the chance of restrictions on going concern opinions to be lower in the first year of the assignment based on a higher reporting error rate of the auditor, based on sanctions by the Stock Exchange Commission (SEC). Factors that affect audit quality are various. The researches on audit quality focus on empirical analysis and the results indicate that audit tenure, audit firm size, auditor independence, etc. Have an impact on audit quality;

Since audit quality is not observable or quantifiable, various proxies are used in prior studies. One commonly used proxy is earnings quality, which is in turn measured using discretionary accruals as a proxy for audit quality (see Balsam, et al 2003) Carey and Simnett (2005) used the type of audit opinion as a proxy for audit quality in examining the relationship between the length of partner tenure and the propensity for audit partners to issue a modified audit opinion. Adeniyi and Mieseigha (2013) and Enofe, Mgbame and Enabosi (2013) measured audit quality by the likelihood that a sampled company employs the services of any of the big four audit firms. A dummy value of 1 is used or ' 0 ' if otherwise.

\subsection{Audit Tenure and Audit Quality}

Prior studies have shown that audit tenure has a significant influence on audit quality. This effect was either positive or negative. Watts and Zimmerman (1983) found that the longer the auditor tenure, the more dependence on clients. Auditor's objectivity and independence will be destroyed and hence, audit quality reduces. Copley and Doucet (1993) opined that the longer the period of engagement, the higher the risk of lower audit quality. This was supported by the findings in: (Arrunada \& Paz-Ares, 1998, Dopuch, King \&Schwarts 2001, Ebrahim, 2001,). Walker, Lewis and Casterella (2001) also investigated the link between the length of the audit engagement and audit failures and found that auditor rotation may not necessarily improve audit quality. Carcello and Nagy (2004) explored the association of changing the auditor and audit quality from the point of view of fraudulent reporting. They found no significant relationships intended of the long-term tenure of the auditors. They concluded that mandatory changes of auditors might have a negative impact on audit quality.

Abedalgader, Ibrahim and Baker (2010) investigated by using discretionary accruals as proxy for audit quality against auditor's tenure and firm size in Jordan and found that 
auditor's tenure is negatively related to audit quality. Adeniyi and Mieseigha (2013) investigated the relationship between audit partners tenure and audit quality. Their result reveals that there is a negative relationship between auditor tenure and audit quality. Summer (1998) analysed the hypothesis that audit tenure will promote audit quality; and concluded that tenure rotation might have an unfavourable effects on audit quality for firms reporting in short term rather than long term engagements as the incentives for building a reputation for honesty. Johnson, Khurama and Reynolds(2002) proxied audit quality by audit tenure as auditor who have served the client's for longer terms would know their client's internal control and accounting system better and would be easier for the auditors to fight earnings management behaviour and other irregularities in client's financial reporting process. Ghosh and Moon (2003) found that investors and information intermediaries perceive auditor's tenure as improving audit quality. Myers, Myers and Omar (2003) found that higher earnings quality with longer audit tenure. Nashwa (2004) investigated the relationship between long-term auditor-client relationship and found that risk increase early in the auditor clientrelationship and declines overtime. Barbadillo and Aguilar (2000) investigated the relationship between auditor tenure and audit quality and suggested that auditors tend to be more dependent in the first years of the auditing engagement.

\subsection{Audit Firm Size and Audit Quality}

DeAngelo (1981) found that auditors with more clients have more to lose by failing to report a discovered breach in a particular client's records when incumbent auditors earn client-specific quasi-rents. Since then many researchers support this conclusion (Teoh\& Wong, 1993, Francis \&Krishman, 1999, Reynolds \& Francis, 2000). Bae and Lee (2013) concluded that audit firm size is positively associated with audit quality measured by discretionary accruals and modified opinions. Also audit firm size is positively associated with audit fees. However, Imhoff (1988) was against DeAngelo's conclusion; he found that from analyst's point of view, there is no difference in audit quality between top-eight audit firms and non-top-eight firms.

\subsection{Auditor Independence and Audit Quality}

DeAngelo (1981) relates the probability of detection to auditor competence and probability of revelation is associated with auditor independence. Due to larger client portfolios, big auditors can exert more pressures on management. Large international accounting firms have established brand reputation and had motives to maintain it by providing high-quality audit. Lack of financial affiliation with clients makes bigger auditors more independent. (Jeong\& Rho, 2004). This independence provides big auditors with stronger negotiation stance with their chart compared with smaller audit firms (Nelson, Elliott \&Tarpley, 2002). Other prior studies that have shown that auditor independence affects audit quality positively, include
(Windsor \& Warning-Rasmussen, 2009 and Alim, Trisni, \& Lilik, 2007). It therefore follows that auditor independence is directly proportional to audit quality.

\section{Methodology}

\subsection{Theoretical Framework and Model Specification}

A framework for the analysis of the relationship between audit firm characteristics and audit quality is the stakeholder theory. The stakeholder theory, originally defined by Freeman (1984,p.120)'is a theory of organizational management and business ethics that addresses morals and values in managing an organization'. In this theory, the concept "stakeholders" refers to managers, shareholders or other users of financial reports which are influenced, either directly or indirectly by the actions of the auditor. A fundamental characteristic of stakeholder theory is therefore to attempt to identify individuals and groups that states, organizations and companies are accountable to. This has also been part of the theory's challenge (Anheier, 2005).

According to Australian Accounting Standard Board (AASB) (2011), variations in stakeholders' perspective of audit quality suggest that no single element should be assured as having the dominant influence on audit quality explained in this study as "audit tenure", "auditor independence, audit firm size and auditor expertise". This means that a broader and deeper understanding of the complexities of the issue needs to be addressed through investigating the impact of these variables more holistically in line with the response Divergent Stakeholders theory (Freeman, 1984). This requires that different stakeholders should carefully analyzed their actions so as to determine the effects of their actions and their impact on the perspectives of audit quality reason been that audits provide assurance to shareholders, managers, investors, creditors and other stakeholders, thus, providing confidence on the financial reporting.

\subsection{Model Specification}

Flowing from the extant empirical literature and the above theoretical frame-work, audit tenure is seen to impact audit quality (Nashwa, 2004; Adeniyi, et al, 2013). Therefore, the relationship between audit tenure and audit quality can be represented as;

$$
\mathrm{AUDQUL}=f(\mathrm{AUDTEN})
$$

In the same vein auditors' independence is believed to influence the quality of audit (DeAngelo, 1981,Nelson et al 2002, Alim, et al, 2007 Windsor \& Warring-Rasmusson 2009).). Therefore, the relationship between auditor independence and audit quality can be expressed as;

$$
\text { AUDQUAL }=f(\text { AUDIND) }
$$

Supposing audit quality depends on audit firm size, even though a mixed relationship has been identified. While some reported positive relationship (e.g DeAngelo 1981, Teoh \& 
Wong 1993, Francis \& Rishman 1999 and Beynolds \& Francis 2000).others believe that a negative relationship exists( Imhoff, 1998 Abedalgader et al 2010 Bae \& Llee, 2013). Therefore, the relationship can be represented as:

$$
\mathrm{AUDQUL}=f(\mathrm{AUDSIZE})
$$

$$
\text { AUDQUL = } f(\text { AUDTEN; AUDIND;AUDSIZE;COYSIZEBODIND) }
$$

In econometric form:

$$
A U D Q U L_{t t}=\alpha_{0}+\alpha_{1} A U D T E N_{i t}+\alpha_{2} A U D I N D_{i t}+\alpha_{3} A U D S I Z E_{t t}+\alpha_{4} C O Y S I Z E_{t t}+\alpha_{5} B O D I N D_{i t}+\mu_{i t}
$$

Where:

AUDQUL
AUDTEN
AUDIND
AUDSIZE
COYSIZE
BODIND
$\mu$
$\alpha_{1}, \ldots, \alpha_{5}$

Audit Quality.

Audit tenure

Auditor independence

Audit firm size

Company size

Board independence

Error term

Unknown coefficient of the variables. It is presumptively expected $\alpha_{1}, \ldots, \alpha_{5}>0$

The variables in the model are operationalised in Table 1 below

Table 1. Measures of variables

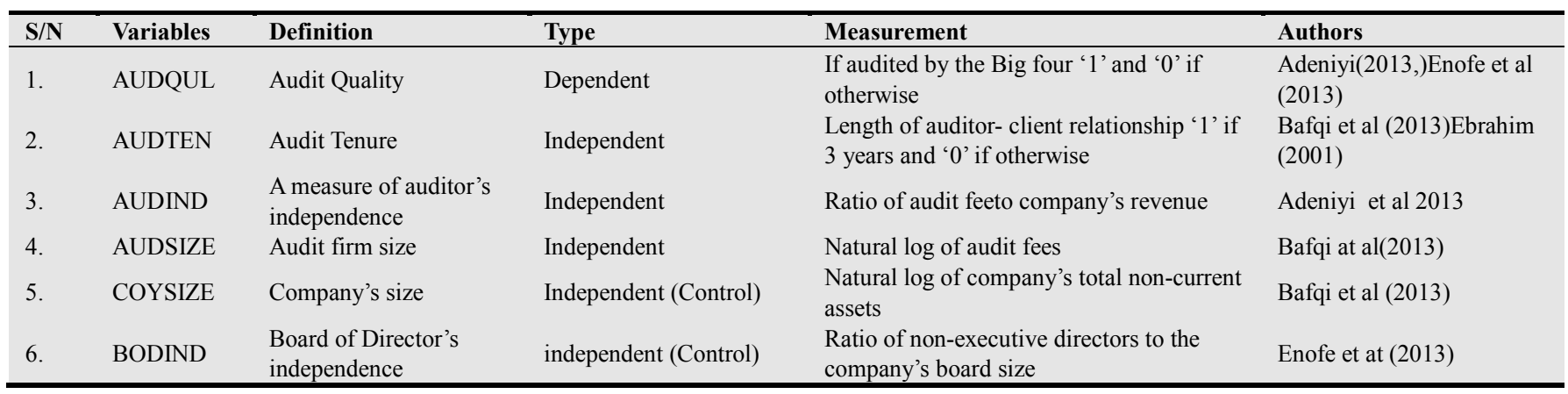

Source: Researcher's Computation, 2014

\section{Data Source and Estimation Technique}

The population of the study comprises the entire companies quoted on the food and beverages sector of the Nigerian Stock Exchange as at $31^{\text {st }}$ December, 2012. Yamane
(1967) model was used scientifically to determine the sample size of 18 companies with relevant data. The study used the panel binary logit and probit technique due to the dichotomous nature of the dependent variable. Prior to the estimation, we carried out the usual regression diagnostic tests of auto-correlation, normality and heteroscedaticity.

\begin{tabular}{|c|c|c|c|c|c|c|}
\hline & Audqual & Audind & Audfsize & Compsize & Bdind & Audten \\
\hline Mean & 0.482517 & 0.086910 & 182.7286 & 71823.99 & 0.463210 & 0.902098 \\
\hline Median & 0.000000 & 0.001349 & 4.200000 & 3562.000 & 0.400000 & 1.000000 \\
\hline Maximum & 1.000000 & 3.607552 & 5350.000 & 2482159. & 2.500000 & 1.000000 \\
\hline Minimum & 0.000000 & $2.58 \mathrm{E}-06$ & 0.240000 & 11.000000 & 0.125000 & 0.000000 \\
\hline Std. Dev & 0.501451 & 0.451513 & 837.0577 & 309047.9 & 0.333422 & 0.298227 \\
\hline Skewness & 0.069973 & 6.028356 & 5.010992 & 6.311460 & 2.860022 & -2.706070 \\
\hline Kurtosis & 1.004896 & 41.15592 & 27.31556 & 46.15292 & 15.10674 & 8.322813 \\
\hline Probability & 0.000007 & 0.000000 & 0.000000 & 0.000000 & 0.000000 & 0.000000 \\
\hline Sum & 69.00000 & 12.42812 & 26130.19 & 10270831 & 66.23900 & 129.0000 \\
\hline Sum Sq.Dev & 35.70629 & 28.94867 & 99494512 & $1.36 \mathrm{E}+13$ & 15.78614 & 12.62937 \\
\hline Observations & 143 & 143 & 143 & 143 & 143 & 143 \\
\hline
\end{tabular}

\subsection{Estimation Result and Discussion}

Table 2. Descriptive Statistics.

Source: Researchers' Computation, 2014 
Table 2 presents the descriptive statistics. As observed, AUDQUAL has a mean value of (0.482517) and a maximum value of (1.000000). The standard deviation of (0.501451) is considerably low and suggests that audit quality across the sample size exhibits considerable clustering around the mean. Audit independence has maximum and minimum values of (3.607552) and (2.58E-06) respectively with a mean value of (0.0869 10). The standard deviation of $(0.451513)$ shows no significant deviation from the mean. The variable of AUDFSIZE has maximum and minimum values of (5350.000) and (0.240000) respectively with a standard deviation of (837.0577) which suggests a considerable variation or dispersion from the mean value of (182.7286). The COMPSIZE variable has a mean value of (71823.99) and a maximum value of (2482159) and a minimum value of (1 1.00000). The standard deviation of (309047.9) shows a significant dispersion from the mean. The other variables BDIND and AUDTEN exhibited considerable clustering around the mean. The Jarque Bera statistics revealed fairly large values which indicates that the data satisfy normality as well as the absence of outliers in the series.

Table 3. Result of the Correlation Analysis

\begin{tabular}{|c|c|c|c|c|c|c|}
\hline \multicolumn{7}{|l|}{ Correlation } \\
\hline \multicolumn{7}{|l|}{ t-Statistic } \\
\hline Probability & Audqual & Audind & Audfsize & Compsize & Bdind & Audten \\
\hline AUDQUAL & 1.000000 & & & & & \\
\hline \multirow[t]{3}{*}{ AUDIND } & -0.132665 & 1.000000 & & & & \\
\hline & -1.589361 & ------ & & & & \\
\hline & 0.1142 & ----- & & & & \\
\hline \multirow[t]{3}{*}{ AUDFSIZE } & -0.202617 & 0.505185 & 1.000000 & & & \\
\hline & -2.456902 & 6.950939 & ----- & & & \\
\hline & 0.0152 & 0.0000 & ----- & & & \\
\hline \multirow[t]{3}{*}{ COMPSIZE } & 0.115824 & -0.043600 & 0.270872 & 1.000000 & & \\
\hline & 1.384650 & -0.518210 & 3.341339 & ----- & & \\
\hline & 0.1683 & 0.6051 & 0.0011 & ----- & & \\
\hline \multirow[t]{3}{*}{ BDIND } & 0.160550 & 0.076492 & 0.045071 & -0.108050 & 1.000000 & \\
\hline & 1.931485 & 0.910963 & 0.535734 & -1.290576 & ----- & \\
\hline & 0.0554 & 0.3639 & 0.5930 & 0.1990 & ----- & \\
\hline \multirow[t]{3}{*}{ AUDTEN } & -0.152798 & 0.062420 & 0.065843 & 0.026156 & 0.069996 & 1.000000 \\
\hline & -1.835939 & 0.742644 & 0.783548 & 0.310686 & 0.833206 & ----- \\
\hline & 0.0685 & 0.4589 & 0.4346 & 0.7565 & 0.4061 & ----- \\
\hline
\end{tabular}

Source: Researchers' Computation, 2014

To address the basic regression assumptions, we tested for multicollinearity using covariance analysis as presented in Table 2. The results show a combination of positive and negative relationship among the variables. While positive relationship can be seen between company size and audit quality, board independence and audit quality, there appears to be a negative relationship between audit committee independence, audit firm size and audit quality.

The test of multicollinearity was further strengthened using the variance inflation factor test. From the results as presented in Table 3, it was observed that none of the variables tested indicates the presence of multicollinearity as the centered VIF of the variables were all less than 10 .

Table 4. Result of the Variance Inflation Factors

\begin{tabular}{llll}
\hline & Coefficient & Uncentered & Centered \\
\hline Variable & Variance & VIF & VIF \\
C & 0.018486 & 11.71220 & NA \\
AUDIND & 0.011014 & 1.465364 & 1.412655 \\
AUDFSIZE & $3.45 \mathrm{E}-09$ & 1.595392 & 1.522335 \\
COMPSIZE & $1.91 \mathrm{E}-14$ & 1.210779 & 1.148320 \\
BDIND & 0.014641 & 3.014233 & 1.023982 \\
AUDTEN & 0.018057 & 10.32051 & 1.010399 \\
\hline
\end{tabular}

Source: Researchers' Computation, 2014

Table 5. Result of the Heteroskedasticity Test

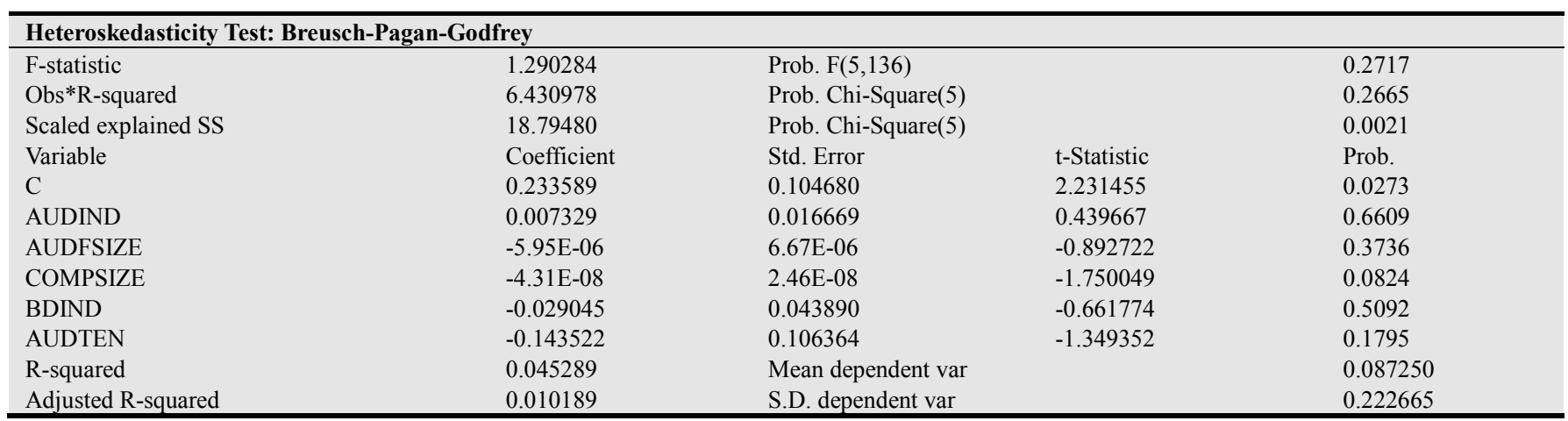




\begin{tabular}{llll}
\hline \multicolumn{1}{l}{ Heteroskedasticity Test: Breusch-Pagan-Godfrey } & & \\
\hline S.E. of regression & 0.221528 & Akaike info criterion & -0.135203 \\
Sum squared resid & 6.674137 & Schwarz criterion & -0.010309 \\
Log likelihood & 15.59941 & Hannan-Quinn criter. & -0.084451 \\
F-statistic & 1.290284 & Durbin-Watson stat & 1.937463 \\
Prob(F-statistic) & 0.271682 & & \\
\hline
\end{tabular}

Source: Researchers' Computation, 2014

The Breusch-Pagan-Godfrey test of heteroskeclacity was conducted to test the serial correlation of the error term. The result of the study as presented in Table 4 shows the absence of heteroskedasticity. Hence, we accepted the null hypothesis of homoskedastic error term. This means the error variance is not serially correlated.
Using the Breusch-Godfrey serial correlation (LM) test, the null hypothesis of no serial correlation was accepted. The Durbin-Watson statistic of (1.9981e2) in Table 4/5 indicates the absence of serial correlation since the DW statistic is substantially close to (2.00).

Table 6. Result of the Breusch-Godfrey Serial Correlation LM Test

\begin{tabular}{|c|c|c|c|c|}
\hline \multicolumn{5}{|c|}{ Breusch-Godfrey Serial Correlation LM Test: } \\
\hline F-statistic & 0.869674 & Prob. F(2, & & 0.4215 \\
\hline Obs*R-squared & 1.833075 & Prob. Chi & & 0.3999 \\
\hline Variable & Coefficient & Std. Error & t-Statistic & Prob. \\
\hline $\mathrm{C}$ & -0.008641 & 0.148497 & -0.058192 & 0.9537 \\
\hline AUDIND & 0.018730 & 0.090302 & 0.207415 & 0.8360 \\
\hline AUDFSIZE & $-8.05 \mathrm{E}-07$ & $5.63 \mathrm{E}-05$ & -0.014293 & 0.9886 \\
\hline COMPSIZE & $2.75 \mathrm{E}-09$ & 7.69E-08 & 0.035784 & 0.9715 \\
\hline BDIND & 0.020707 & 0.101189 & 0.204640 & 0.8382 \\
\hline AUDTEN & 0.002760 & 0.079074 & 0.034901 & 0.9722 \\
\hline $\mathrm{AR}(1)$ & -0.038343 & 0.085348 & -0.449257 & 0.6540 \\
\hline RESID(-1) & 0.003046 & 0.124806 & 0.024409 & 0.9806 \\
\hline RESID(-2) & 0.132277 & 0.111050 & 1.191152 & 0.2357 \\
\hline R-squared & 0.012909 & \multicolumn{2}{|c|}{ Mean dependent var } & $-8.89 \mathrm{E}-12$ \\
\hline Adjusted R-squared & -0.046465 & \multicolumn{2}{|c|}{ S.D. dependent var } & 0.296427 \\
\hline S.E. of regression & 0.303236 & \multicolumn{2}{|c|}{ Akaike info criterion } & 0.512672 \\
\hline Sum squared resid & 12.22962 & \multicolumn{2}{|c|}{ Schwarz criterion } & 0.700013 \\
\hline Log likelihood & -27.39968 & \multicolumn{2}{|c|}{ Hannan-Quinn criter. } & 0.588799 \\
\hline F-statistic & 0.217418 & \multicolumn{2}{|c|}{ Durbin-Watson stat } & 1.998142 \\
\hline Prob(F-statistic) & 0.987346 & & & \\
\hline
\end{tabular}

Source: Researchers' Computation, 2014

Table 7. Result of the Binary Probit

\begin{tabular}{|c|c|c|c|c|}
\hline Variable & Coefficient & Std. Error & z-Statistic & Prob. \\
\hline $\mathrm{C}$ & 0.005869 & 0.406136 & 0.014450 & 0.9885 \\
\hline AUDIND & 0.796364 & 0.855346 & 0.931043 & 0.3518 \\
\hline AUDFSIZE & -0.003554 & 0.001928 & -1.843365 & 0.0653 \\
\hline COMPSIZE & $6.42 \mathrm{E}-06$ & $3.30 \mathrm{E}-06$ & 1.946339 & 0.0516 \\
\hline BDIND & 1.275612 & 0.464750 & 2.744730 & 0.0061 \\
\hline AUDTEN & -0.764762 & 0.393304 & -1.944456 & 0.0518 \\
\hline McFadden R-squared & 0.183181 & \multicolumn{2}{|c|}{ Mean dependent var } & 0.482517 \\
\hline S.D. dependent var & 0.501451 & \multicolumn{2}{|c|}{ S.E. of regression } & 0.457024 \\
\hline Akaike info criterion & 1.215269 & \multicolumn{2}{|c|}{ Sum squared resid } & 28.61536 \\
\hline Schwarz criterion & 1.339584 & \multicolumn{2}{|c|}{ Log likelihood } & -80.89170 \\
\hline Hannan-Quinn criter. & 1.265784 & \multicolumn{2}{|l|}{ Deviance } & 161.7834 \\
\hline Restr. deviance & 198.0652 & \multicolumn{2}{|c|}{ Restr. log likelihood } & -99.03262 \\
\hline LR statistic & 36.28183 & \multicolumn{2}{|c|}{ Avg. log likelihood } & -0.565676 \\
\hline Prob(LR statistic) & 0.000001 & \multirow{3}{*}{\multicolumn{2}{|c|}{ Total obs }} & \\
\hline Obs with Dep $=0$ & 74 & & & 143 \\
\hline Obs with Dep=1 & 69 & & & \\
\hline
\end{tabular}

Source: Researchers' Computation, 2014

The results of the binary probit are presented in Table 6 . The McFadden R-squared value of (0.183181) shows explanatory power of $18.3 \%$. On the basis of the performance of the individual variables, it was discovered that about three variables appear to be statistically insignificant. More specifically, the variable of board independence was found to be statistically significant and positive with a robust coefficient of (1.2756 12) and a significant z-statistic of (2.744730). The implication of this is that board independence has the likelihood of influencing 
audit quality. That means an independent board is likely to enhance quality audit in any organization. This is because the oversight function of the board is likely to be forceful with an independent board. In the same vein, the control variable of company size is seen to be significant and positive. The implication of this is that with larger company size, the quality of audit is likely to increase. Bigger companies are likely to attract more professionals that will positively affect the reporting quality of the organization and by extension, quality audit. The variable of audit tenure was negative and statistically significant having reported a t-value of (1.944456) and a robust coefficient of (-0.764762). This means audit tenure is more likely to have a negative effect on audit quality. The implication of this is that the long run relationship is likely to threaten the independence of the auditor and by extension audit quality. The result is consistent with the negative relationship reported by Davis,
Soo and Trompeter, (2003) and Carcello and Nagy (2004).

Audit firm size was also found to be negative though statistically insignificant. This means a large audit firm is more likely to produce lesser quality audit. This is liken to produce lesser quality audit. This is likened to the "too big to fail" syndrome of Nigeria banks which saw the demise of large banks such as Intercontinental, Oceanic, to mention a few. The case of Arthur Anderson is still fresh in our memory; therefore, the negative relationship between the size of the audit firm and audit quality is not unexpected. This finding disagreed with the findings of previous studies (e.g. Teoh \& Wong, 1993, Francis \& Krishman, 1999, Reynolds \& Francis, 2000). The variable of audit independence was positive but not statistically significant. This means the independence of the auditor is likely to increase audit quality. This position is consistent with Alim, Trisni and Lilik (2007), Windson, Warring and Rasmussen (2009).

Table 8. Result of the Binary Logit

\begin{tabular}{llll}
\hline Variable & Coefficient & Std. Error & z-Statistic \\
\hline C & 0.015959 & 0.667699 & 0.023901 \\
AUDIND & 1.319205 & 1.481738 & 0.890309 \\
AUDFSIZE & -0.006015 & 0.003274 & -1.836955 \\
COMPSIZE & $1.07 \mathrm{E}-05$ & $5.62 \mathrm{E}-06$ & 1.911654 \\
BDIND & 2.035709 & 0.764445 & 2.662990 \\
AUDTEN & -1.225878 & 0.646257 & -1.896890 \\
McFadden R-squared & 0.181354 & Mean dependent var & 0.0662 \\
S.D. dependent var & 0.501451 & S.E. of regression & 0.0559 \\
Akaike info criterion & 1.217799 & Sum squared resid & 0.0578 \\
Schwarz criterion & 1.342114 & Log likelihood & 0.482517 \\
Hannan-Quinn criter. & 1.268315 & Deviance & 0.457279 \\
Restr. deviance & 198.0652 & Restr. log likelihood & 28.64730 \\
LR statistic & 35.91993 & Avg. log likelihood & -81.07265 \\
Prob(LR statistic) & 0.000001 & & 162.1453 \\
Obs with Dep=0 & 74 & Total obs & -99.03262 \\
Obs with Dep=1 & 69 & & -0.566942 \\
\hline
\end{tabular}

Source: Researchers' Computation, 2014

The result of the binary logit is not significantly different from the result of the binary probit. The McFadden Rsquared value of the binary logit is estimated to be (0.81354) which means an explanatory power of $(0.181354)$. The variable of board independence has a positive coefficient of (2.035709) which is considered very robust. The $\mathrm{z}$-statistic is (2.662990) which is statistically significant. This means board independence has the likelihood of increasing the quality of audit in an organization that appears to be the same result reported in the binary probit presentation.

Similarly, audit tenure was found to be significant with a coefficient of (- 0.764762) though negative but significant with a probability value of $(0.005)$. This means longer audit tenure may likely reduce the quality of audit. The result is consistent with the binary probit which also reported negative relationship between audit tenure and audit quality. The variable of audit firm size was found to be negative with a coefficient of (-0.006015) and a z-statistic of (-1.836965) which is considered not significant. As mentioned earlier, it means larger audit firms have the likelihood of delivering lesser quality audit. This is probably the result of divided attention as a result of the larger number of clients being attracted to the big audit firms. Audit independence was also found to be statistically insignificant in the binary logit with a t-value of (0.02390).

\section{Summary of Findings, Conclusion and Recommendations}

\subsection{Summary of Findings}

Based on the result the following summary of findings is provided:

1. Board independence has the likelihood of influencing audit quality.

2. Firm size has the likelihood to increase the quality of audit

3. Audit tenure has the likelihood to reduce the quality of audit

4. Audit firm size has likelihood to reduce audit quality

5. Auditor independence is positively associated with firms' audit quality but not statistically significant 


\section{Conclusion}

This study examines the relationship between firm characteristic and quality of audit. The study reveals that firm size has the likelihood to increase audit quality; audit tenure and audit firm size has the likelihood to reduce audit quality while audit independence increases audit quality.

\section{Recommendations}

Against the backdrop of the findings, we advanced the following recommendations

1. Firms in Nigerian should ensure that their boards are independent as this is likely to enhance audit quality.

2. The Nigerian Stock Exchange should relax its stringent listing requirements so that firms can be listed on the first tier since larger firms engage the services of professionals which by extension will positively affect the audit quality.

3. The three years professional requirement for an auditor in Nigeria should be backed up by law and enforced. Since audit tenure has a negative relationship with audit quality

4. Since audit firm size reduces the quality of audit, smaller audit firm should be encouraged as they are likely to carry out a more thorough audit assignment.

\section{Suggestions for Further Studies}

The present study spanned a seven-year period covering 2005 to 2012 and the selected samples included only listed food and beverage companies in Nigeria. It is therefore suggested that the study be extended to a longer period and more samples.

\section{References}

[1] Abedalgader, A., Ibrahim, T. R., \& Baker, R. A. (2010). Do audit tenure and firm size contribute to audit quality? Journal of Managerial Auditing, 26(3), 317 - 334.

[2] Adeniyi, S. I. \&Mieseigha, L. G. (2003). Audit tenure: An assessment of its effects on audit quality in Nigeria. International Journal of Academic Research in Accounting, Finance and Management Science, 3(3), 275 - 283.

[3] Arens, A. A. \&Loebbecke, J. K. (1997).Auditing: An integrated approach. Upper Saddle River, NJ: Prentice Hall.

[4] Arrunada, B. \& Paz-Ares, C. (1998). Mandatory rotation of company auditors: A critical examination.International Review of Law and Economics, 17(1), 31 - 61.

[5] Arrumade, B. (2000). Audit quality: attributes, private safeguards and the role of regulation. The European Accounting Review, 9(2), 205 - 225.

[6] Bae, G. S. \& Lee, J. E. (2003). Does audit firm size matter? The effect of audit firm size measured by audit firm revenue, number of offices and professional headcounts on audit quality and audit fees.Journal of Accounting Research, 50(20), 10 - 17.
[7] Balsam, S., Krishran, J. \& Yang, S. J. (2003). Auditor industry specialization and earnings quality.Auditing:A Journal of Practice and Theory, 22(3), 71 - 97.

[8] Barbadillo, E. \& Aguilar, N. (2008). Does auditor tenure improve audit quality? Mandatory auditors rotation versus long term auditing. An empirical analysis.Working Paper, University of Cadizi Spain.

[9] Beattice, V. \&Fearnley, S. (1995). The importance of audit firm characteristics and the drivers of auditor change in UK listed companies, Accounting and Business Research, 25(2), $227-239$.

[10] Bolanle, A. B., Olanrewaju, A. S., \&Muyideen, A. A. (2012). Corporate social responsibility and profitability of Nigeria's banks: A casual relationship. Research Journal of Finance and Accounting, 3(1), 6- 17.

[11] Carcello, J. V. \&Palmrose, Z. (1994).Auditor litigation and modified reporting on bankrupt clients, Journal of Accounting Research,32(Supplement)1 - 30.

[12] Carcello, J. V., \& Nagy, A. L. (2004).Audit firm tenure and fraudulent financial reporting.Auditing: A Journal of Practice and Theory, 23(2), 55-69.

[13] Copley, P. \&Doncent, M. (1993). Auditor tenure fixed fee contracts and the supply of substandard single audits, Public Budgeting and Finance, 13, $23-35$.

[14] Davis, L. R., Soo, B., \&Trompeter, G. (2003).Audit tenure, auditor's independence and earnings management, Working Paper, Boston College.

[15] DeAngelo, L. E. (1981). Auditor size and audit quality.Journal of Accounting and Economics, 3, (1981)183 - 199.

[16] Dezoort, F. T., \&Salterio, S. E. (2001). The effect of corporate governance experience and financial reporting and audit knowledge on audit committee membersjudgements; Auditing: A Journal of Practice and Theory, 20(2), 31 - 47.

[17] Dopuch, N. D., King, R. R., \& Schwartz, R. (2001).An experimental investigation of reputation and rotation requirements. Journal of Accounting Research, 39 (1), 93 117.

[18] Ebrahim, A. (2001). Auditing quality, auditor tenure, client importance and earnings management: An additional evidence. Working Papers, Rutgers University.

[19] Enofe, D.O.; Mgbame, C.O\&EnabosiO.C. (2013).Corporate Governance and Audit Quality in Nigeria. ESUT Journal of Accountancy, 4(1), 138-145

[20] Francis, J. R. \&Krishman, J. (1999).Accounting accruals and auditor reporting conservatism.Contemporary Accounting Research, 16(1), 135 - 166.

[21] Francis, J. R. (2004). What do we know about audit quality? British Accounting Review, 36(4), 345 - 368.

[22] FRC (2006b). Promoting audit quality, Discussion Paper, London: Financial Reporting Council.

[23] FRC (2008). The audit quality framework: London: Financial Reporting Council.

[24] Freeman, E. (1984). Strategic management: A stakeholder approach. Boston: Pitman Publishing. 
[25] Geiger, M. A., \&Raghumandari, K. (2002).Auditor tenure and audit reporting failures.Auditing, 21, (2) $67-78$.

[26] Ghosh, A. \& Moon, D. (2003).Auditor tenure and perceptions of auditor quality.The Accounting Review, 80(2), 585 - 612 .

[27] IAASB (2011). Audit quality: An IAASB perspective, International Auditing and Assurance Standards, Board, New York.

[28] Imhoff, E. A. (1988). The effects of ex-arile earnings uncertainty as earnings response coefficient.The Accounting Review, 67(2), $427-439$.

[29] Jackson, A. B., Moldrich, M., \& Roebuck, J. K. (2002). Audit-firm tenure and the quality of financial reports. Contemporary Accounting Research, 19 (4), 637 - 660.

[30] Jenkis, D. S., Kane, G. D., \&Velury, U. (2006).Earnings quality decline and the effect of industry specialist auditors, Journal of Accounting and Public Policy, 25(3), 71 - 90.

[31] Johnson, V., Khorana, I. K., \& Reynolds, J. K. (2002).Audit firm tenure and the quality of financial reports, Contemporary Accounting Research, 19, 637 - 660.

[32] Lee, C. J., Liu, C. \& Wang, T. (1999).The 150-hour rule.Journal of Accounting and Economics, 27(2), 203 - 228.

[33] Mitra, S. \&Hossdin, M. (2010). Auditor's industry specialists and earnings management of firm reporting internal control weaknesses under SOX section 404. Working Paper, Wayne State University and Fogelman College.

[34] Mock, T. J. \& Smith, D. (1982). A multi-attribute model for audit evaluation.In Proceedings of the V.I. University of Kanas Audit Symposium.

[35] Moizer, P. (1998). Company director's view on the performance of the 1987 Big Eight and the 1996 Big Six, Leeds University Business School Working Paper.

[36] Myers, J. N., Myers, L. A., \& Omer, C. T. (2003).Exploring the term of the auditor-client relationship and the quality of earnings: A case for mandatory auditor rotation.The Accounting Review, 78(3), 779 - 799.

[37] Nashnea, G. (2004). Auditor's Rotation and the quality of audits. The CPA Journal, 74(12), $22-26$.

[38] Nelson, M., Elliott, J., \&Turpley, R. (2002). Evidence fro auditors about manager's and auditor's earnings management.
The Accounting Review, 77 (Supplement), 175 - 202.

[39] Reynolds, J. K. \& Francis, J. R. (2000). Does size matter? The influence of large clients on office-level auditor reporting decisions.Journal of Accounting and Economics, 30, 375 400 .

[40] Schroeder, M. S., Solomon, I. \& Vickery, D. W. (1986). Audit quality: The perceptions of audit committee chairperson and audit partners, auditing: A journal of Practice and Theory, $5(1), 86-94$.

[41] Simunic, D. \& Stein, M. (1996). The impact of litigation risk on audit pricing: A review of the economics and the evidence, Auditing: Journal of Practice and Theory, 15 (supplement), $119-134$.

[42] Simunic, D. (1980). The pricing of audit services: Theory and evidence, Journal of Accounting Research (Spring), 161 - 190.

[43] Solomon, I., Shields, M., Whittington, O. R. (1999). What do industry-specialist auditors know? Journal of Accounting Research, 37(1), $191-208$.

[44] Summer, M. (1998). Does mandatory rotation enhance auditor independence? European Accounting Review, 9(2), 205 - 224.

[45] Teoh, S. H., \& Wong, T. J. (1993).Perceived auditor quality and the earnings response coefficient.The Accounting Review, $68,346-366$.

[46] Titman, S. \&Trueman, B. (1986).Information quality and the valuation of new issues.Journal of Accounting and Economics, $8(2), 159-172$.

[47] Vanstraelen, A. (2000). Impact of renewable long-term audit mandates on audit quality, European Accounting Review, 9(3), 419-442.

[48] Watts, R. \&Zimmeranson, J. (1983). Agency problems, auditing and the theory of the firm: Some evidence. Journal of Law and Economic, 26(3), 613 - 633.

[49] Windor, C. \& Warning-Rasmussen, B. (2009). The rise of regulatory capitalism and the decline of auditor independence: A critical and experimental examination of auditor's conflicts of interests. Critical Perception of Accounting, 20(2), 267 288.

[50] Yamane,T.(1967).Elementory sampling theory. Retrieved from www.Jstor.org/stable/2284149 